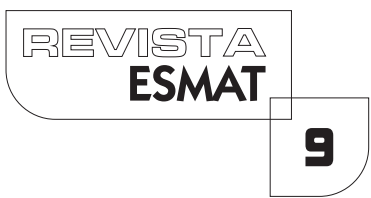

\title{
CORRELAÇÕES ENTRE A JUSTIÇA RESTAURATIVA E A COMUNICAÇÃO NÃO VIOLENTA COM A EDUCAÇÃO
}

Denilson Barbosa de Castro

Professor Assistente da Universidade Federal do Tocantins (UFT); pesquisador do Núcleo Interdisciplinar de Educação em Direitos Humanos (NIEDIH/UFT), e bolsista da Fundação de Apoio Científico e Tecnológico do Tocantins (FAPTO).

Paulo Fernando de Melo Martins

Professor Adjunto da Universidade Federal do Tocantins (UFT); pesquisador do Núcleo Interdisciplinar de Educação em Direitos Humanos (NIEDIH/UFT), e professor-pesquisador no Programa de Pós-Graduação Stricto Sensu em Prestação Jurisdicional e Direitos Humanos - Mestrado Profissional Interdisciplinar.

\section{RESUMO}

O presente artigo objetiva analisar a relação entre a Justiça Restaurativa (JR) e a Justiça Retributiva (JR), sob o olhar da Comunicação Não Violenta (CNV). Esta análise se faz presente porque as premissas fundamentais da Justiça Restaurativa podem ser alocadas em situações cotidianas de foro mais casual, mas sem que ocorram todos os aspectos da formalidade jurídica. Assim, a Comunicação Não Violenta pode ser empregada em ambientes nos quais ocorram relações sociais na família, na escola, na justiça, no trabalho e outras, mediadas por pessoas conscientes de seu papel conciliador. A Justiça Restaurativa e a Mediação de Conflitos são práticas recentes e se tornam propostas inovadoras para a conciliação de conflitos, como também corroboram para a melhoria da qualidade de vida relacional das pessoas e da democracia.

PALAVRAS-CHAVE: Comunicação Não Violenta. Direitos Humanos. Educação. Justiça Restaurativa.

\section{ABSTRACT}

The following article aims to analyze the engagement between Restorative Justice and Retributive Justice, under the view of the Non-violent Communication. The analysis is valid once the fundamental assumptions of Restorative Justice are able to be seen on daily routines, which means, in a more casual environment without the complete imperative presence of Legal Conditions; therefore, the Non-violent Communication can be 
inserted to environments where social relations are strongly present - family, school, by the view of Justice, work and other environments where there's a present and conscience pacifier figure. Restorative Justice and Conflict Mediation are recent practices, and are considered to be innovative solutions to appease conflicts, as it corroborates to improve the quality of people's relations and, Democracy.

KEYWORDS: Non-violent Communication. Human Rights. Education. Restoring Justice. Restorat.

\section{INTRODUÇÃO}

Este artigo tem o intuito de debater as relações entre a Justiça Restaurativa (JR) e a Comunicação Não Violenta (CNV) em todos os setores sociais, mas com especial atenção para a sua utilização no ambiente escolar. Por isso, o objetivo principal reside em analisar os principais aspectos da Justiça Restaurativa observando os diferentes contextos da restauração de conflitos por meio da Comunicação Não Violenta na construção e consolidação de seu protagonismo na sociedade.

A análise deste tema poderá representar um novo viés do sistema judiciário, de modo a determinar novas fronteiras para resolução de conflitos, principalmente a todos aqueles ligados às questões da violência. Esse debate está em sintonia com as propostas desenvolvidas pelo Direito Alternativo, que busca, por meio do diálogo, solucionar situações de inexistência deste, da falta de autonomia entre as partes em conflito, em que a Justiça Restaurativa interfere na interpretação legalista da Lei e sugere ou media o diálogo entre as partes como medida solucionadora de conflitos.

Este artigo baseia-se nos pressupostos teóricos de ZEHR (2008; 2012), ROSENBERG (2006), PRANIS (20 I0), SUANNO (20 I 3) e outros(as). Nossa análise terá como linha descritiva as concepções dos(as) autores(as) citados(as) e outros(as), bem como dos processos interpretativos voltados para uma análise dialética das estruturas conceituais que permeiam este texto.

As práticas de resolução de conflitos propõem que a principal ação de restauro reside em alocar, no mesmo espaço físico, o autor do ato de violência ou ato infracional e a vítima agredida, para que possam dialogar e buscar soluções para uma situação de conflito. Familiares dos dois lados também podem participar do processo de discussão, em que a autonomia e o diálogo se tornam peças fundamentais para a sua realização, pois se não houver ética entre as partes não se chegará a lugar algum. 
O diálogo torna-se o ponto principal para a consolidação do processo restaurativo, mas, além de ser observado o dano ou delito cometido, há a necessidade também de se observar a vítima, esta se torna o foco das questões relacionais da Justiça Restaurativa; porém, o conceito sobre o termo vítima é complexo, pode ser definido

[...] como aquele que sofre as conseqüências de determinada conduta típica, de modo relevante, que propicia a atuação do Estado para atingir os fins do direito penal, no Estado Democrático de Direito. Neste conceito ficam abrangidas todas as possíveis categorias de vítimas, tanto as pessoas físicas como as pessoas coletivas, ou aquelas que, na atualidade, sofrem as conseqüências de ações que atingem bens jurídicos difusos ou coletivos (GRECO, 2004, p. 19).

A proposta principal da Justiça Restaurativa baseia-se em promover de alguma forma a restauração, neste caso, de um conflito. Para que este conflito inexista, é preciso que ocorra por todos(as) os(as) envolvidos(as) a responsabilidade social/ativa (não agressão física ou verbal), em que a proposta de colocar frente a frente as partes envolvidas, agressor(a) e agredido(a) possa se tornar proposta de inclusão social.

Este processo de interligação entre as pessoas, de respeitabilidade de opiniões e decisões são peças fundantes da origem da Justiça Restaurativa, suas influências estão centradas em análises antropológicas da cultura "Maori", os Maori são aborígenes da Nova Zelândia que há séculos solucionam seus "litígios" pelo diálogo. Sua construção também sofreu influências de comunidades indígenas do Canadá e de tribos africanas. A partir da década de 70, são experimentadas as primeiras ações não indígenas da mediação de conflitos entre agressor e vítima.

As relações conflituosas nessas comunidades "primitivas" são dialogadas entre todos(as). O conflito passa a ser de responsabilidade de todos(as) os(as) envolvidos(as). Em nossa sociedade atual, um conflito gerado pode ser entendido como delito à ordem pré-estabelecida na sociedade, assim, segundo Zehr (2008), ao ser praticado um delito, gera-se um "crime". Essa ação corresponderá a um ato indevido, deverá ter a observância da Lei, pois se romperam as regras de conduta para com o Estado; em contrapartida, também nos instiga a refletir sobre os conceitos atrelados a este ato.

O crime também representa um relacionamento dilacerado entre vítima e ofensor. Mesmo se eles não tinham um relacionamento prévio, o delito cria um vínculo, que em geral é hostil. Se não resolvido, esse relacionamento hostil afetará. Por sua vez, o bem-estar da vítima e do ofensor (ZEHR, 2008, p. I 7 I). 
Essa análise poderá ser observada nas relações conflituosas, pois todos os comportamentos sociais geram conflitos a todo o momento, e quando não resolvidos geram instabilidades entre as partes, podendo haver um ato infracional. Este agir desagrava a natureza da Lei, impondo à sociedade e ao agredido um delito ou crime contra a sua pessoa e a ordem estabelecida.

Segundo Zehr(2008),

O crime significa um agravo à vítima, mas poderá também ser um agravo ao ofensor. Muitos crimes nascem de violações. Muitos ofensores foram vítimas de abusos na infância e carecem das habilidades e formação que possibilitariam um emprego e uma vida significativa. Muitos buscam validação e empoderamento. Para eles o crime é uma forma de gritar por socorro e afirmar sua condição de pessoa. Em parte, prejudicam os outros porque foram prejudicados. E não raro são prejudicados ainda mais pelo sistema judicial. Tal dimensão nasce, em certa medida, de outras questões da justiça Retributiva (p. |7I).

Tais situações podem ser comparadas e interpretadas a partir da análise de Sousa (20|3), o qual indica que a

[...] justiça restaurativa visa reparar o dano que o crime causou às partes envolvidas no conflito, não se concentrado apenas na sansão direcionada à penalidade do indivíduo. Ao passo em que busca alcançar a reparação do trauma, o modelo restaurativo visa dar a oportunidade ao infrator de assumir a responsabilidade e reintegrá-lo socialmente, contribuindo, dessa maneira, para a não reincidência criminosa ou infracional. (p. 100)

agir em conjunto é uma prática social difícil de ser vista atualmente, mas não impossível de ser alcançada, basta querer. Devemos refletir constantemente sobre as nossas ações cotidianas, para que não nos envolvamos em situações de conflito.

Segundo as observações de Almeida (s/d), 'o conceito e a filosofia de justiça restaurativa têm embasado programas sociais dedicados a cuidar das vítimas, dos ofensores e das comunidades que os abrigam, e orientado para a restauração de suas vidas e de sua interação social. Em suas análises, a autora

'Consultora, docente e supervisora em Mediação de Conflitos. Sócio-fundadora e diretorapresidente do MEDIARE - Diálogos e Processos Decisórios. Disponível: http://www.mediare.com.br/08artigos_06justica_restaurativa.html 
comenta que o que se discute não é o delito em si, mas as suas conseqüências. A partir do delito geram-se os conflitos e estes precisam ser tratados. A Justiça aborda somente o delito, as relações sociais decorrentes deste não são vistas, na maioria dos casos, pelo Estado.

Assim, segundo Almeida(s/d),

O poder de síntese e de informação veiculado pelos quadros comparativos nos auxiliará a visualizar um leque de diferenças entre a proposta retributiva e a proposta restaurativa de justiça, demonstradas pelo esquema publicado por Highton, Alvarez e Gregório em 'Resolución Alternativa de Disputas y Sistema Penal'.

Essa proposta se baseia em premissas que norteiam a justiça retributiva e a justiça alternativa, sua análise se faz presente a partir do quadro abaixo:

\begin{tabular}{|l|l|l|}
\hline & \multicolumn{1}{|c|}{ Justiça Retributiva } & \multicolumn{1}{|c|}{ Justiça Restaurativa } \\
\hline Delito & Infração da norma & Conflito entre pessoas \\
\hline Responsabilidade & Individual & Individual e social \\
\hline Controle & Sistema penal & Sistema penal / Comunidade \\
\hline Protagonistas & Infrator e o Estado & Vítima, vitimário e comunidade \\
\hline Procedimento & Adversarial & Diálogo \\
\hline Finalidade & $\begin{array}{l}\text { Provar delitos. Estabelecer } \\
\text { culpas. Aplicar castigos }\end{array}$ & $\begin{array}{l}\text { Resolver conflitos. } \\
\text { Assumir responsabilidades. } \\
\text { Reparar o dano }\end{array}$ \\
\hline Tempo & Baseado no passado & Baseado no futuro \\
\hline
\end{tabular}

Quadro 1. Quadro comparativo entre a Justiça Retributiva e a Justiça Alternativa. Fonte: Tania Almeida.

Pode-se observar existirem diferenças significativas entre a Justiça Retributiva e a Justiça Restaurativa. Desde o processo colonizatório brasileiro aprofundaram-se as aplicações e as tradições de "execução" e "exceção" da justiça, espera-se que, de alguma forma, a justiça seja realizada, mas esta se realiza pela imposição do Estado. Este poder se consolida a partir da Proclamação da República com o apoio do poder local (no passado o coronelismo). 
Em contraposição a essa afirmação de poderes por parte do Poder do Estado e dos mandatários locais é a democracia participativa. Essa prática democrática determina que todos(as) devem colaborar e participar das decisões entre si e, ao ser aprovada pela maioria, a sua participação torna-se conjunta entre a sociedade e o Poder Público. Sua base de sustentação centrase no debate, no diálogo e na aceitação de decisões.

Esses conceitos também formam a base da Justiça Restaurativa, seus princípios podem ser mensurados por palavras que determinam vários sentimentos sociais, como: o respeito; a honestidade; a humildade; a responsabilidade; o empoderamento; a justiça; a participação; e o companheirismo. Ao promover a Justiça Restaurativa, inicia-se outra fase de todo um processo que está intimamente ligado à Comunicação Não Violenta. Todos esses valores e outros mais não elencados devem ser vistos em relação ao olhar para o ato infracional.

Assim, a Comunicação Não Violenta baseia-se num processo de intervenção mais amplo, envolve também, além dos(as) inseridos(as) no conflito, outras pessoas. A Comunicação Não Violenta inicia-se a partir de análises do psicólogo estadunidense Marshall Rosenberg. Sua pesquisa se desenvolve a partir das últimas décadas do século passado, baseada nas ações relacionais básicas do ser humano: saber ouvir e falar. O princípio centra-se em produzir nas relações humanas condições mínimas para que o diálogo possa ser legível (claro) e entendível (compreendido), e as relações dialógicas possam verdadeiramente surtir efeito pessoal e resultados conjuntos.

A cooperação entre as partes passa a ter papel primordial entre a relação de duas pessoas ou de um grupo. Há necessidade de que os(as) envolvidos(as) possam verdadeiramente estar voltados(as) para a "empatia" mútua; o querer estar presente, e o querer resolver determinado conflito ou problema.

A Comunicação Não Violenta afirma que, ao nos relacionarmos com os outros, a empatia ocorre somente quando conseguimos nos livrar de todas as ideias preconcebidas e julgamentos a respeito deles. [...] A presença que a empatia requer não é fácil de manter (ROSENBERG, 2006, p. 134).

A Comunicação Não Violenta apoia-se nas relações humanas, então, situase em conceitos que estão intimamente ligados aos sentimentos humanos, como a opinião sobre o(as) outro(as) (seja ela de características físicas ou pessoais); a consolidação de juízos de valores pessoais ou até mesmo aqueles constituídos pela sociedade (você é isso ou aquilo); construção de sentimentos (que podem ser verdadeiros ou não); na relação entre os pedidos de desculpas e o perdão (podem ou não ser verdadeiros); e na relação de exigir e ameaçar 
(visa apenas ao sentimento, não se observa o(a) outro(a). Ademais, não importa quais palavras os outros usem para se expressar, simplesmente prestamos atenção em suas observações, sentimentos, necessidades e pedidos. [...] Precisamos sentir empatia para dar empatia. (ROSENBERG, 2006, p. I 5 I). Há necessidade de deixar que todos(as) possam se expressar e manifestar livremente seus pensamentos, sem pressa, podendo-se observar, assim, que as falas sejam respeitadas e realizadas sem interrupções dos relatos das pessoas.

A empatia é necessária para que haja compartilhamento, mas é preciso mais, que realmente aceitemos o(a) outro(a) como ele(a) realmente é. Podemos então situar-nos num contexto inicial de como são os nossos objetos de análise, partindo de nossos conceitos pessoais, mas as nossas discussões deverão recair em como produzir ou reproduzir essa teoria em prática, e em como promover verdadeiramente o protagonismo juvenil em todos os setores sociais, principalmente daqueles(as) que estão em situação de risco social ou sob medidas socioeducativas.

\section{OS PRINCÍPIOS FUNDAMENTAIS DAJUSTIÇA RESTAURATIVA}

$\bigcirc$ processo de evolução tecnológica está cada vez mais acelerado e se tornando global, regiões onde a tecnologia não existia já estão conectadas. $\bigcirc$ uso da energia, de aparelhos eletroeletrônicos, do acesso à informação e muitas outras formas de interagir com o mundo facilitam os meios de comunicação e, como consequência, o uso da violência, pois ela se torna presencial, sabe-se em tempo real o que está acontecendo em todo o mundo e se popularizam, várias ações sociais se tornam comuns pelo uso da tecnologia.

Essa aceleração de informações hoje é altamente necessária, mas traz consigo a necessidade de manter cada vez mais presente a informalidade e a execução rápida de uma resposta. Estamos nos acostumando a agir sob um regime de informações que nos induzem a estar satisfeitos com uma resposta e a não contradizê-la, mesmo porque, nos dias de hoje, quem nos dá a resposta é o computador, o telefone celular, o tablet. A multimídia está presente em nossas vidas e na sociedade. A evolução tecnológica está presente em todos os setores sociais, mas precisamos estar atentos e críticos aos diferentes tipos de informação que se nos apresentam.

$\bigcirc$ processo de aceleração das informações traz a necessidade de se obter rapidamente um resultado, este pensamento torna-se usual nas situações cotidianas, na magistratura isso também acontece, pois, à medida que se obtém uma demanda positiva em relação ao julgamento dos processos, faz-se com 


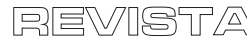

ESMAT

que a justiça seja mais rápida. $\bigcirc$ uso da tecnologia da informação agiliza os julgamentos dos processos, mas poderá influenciar na análise dos casos, tornando uma sentença numa ação meramente mecânica.

Em complementação à Justiça Retributiva, a Justiça Restaurativa baseia-se em apresentar alternativas a situações de risco social e aos tipos de violência existentes na sociedade. No Brasil, o uso da legalidade democrática de direito é condicionante de uma sociedade que segue as cláusulas da Constituição Federal e dos Códigos Jurídicos. O uso da legalidade jurídica utiliza-se dos princípios da democracia, mas, em muitos casos, no ato de impetrar a pena não são observados a realidade social de quem cometeu o crime e seus desníveis sociais e culturais.

Note-se ainda a existência de grande número da população não atendida por programas assistenciais que reside nas áreas de risco social; o desejo capitalista se torna cada vez mais presente e premente para aqueles(as) que estão à margem dos benefícios sociais, e o Estado, por sua vez, não executa programas de prevenção dos malefícios sociais, e sim de contenção, sendo assim, o abismo social ainda existe.

Não vamos debater aqui sobre políticas de governo, não seria o momento, fugiríamos demais do nosso objetivo, mas sim refletir sobre determinado aspecto. As reais condições da sociedade brasileira com o aumento da renda familiar trouxeram consigo a busca de novas perspectivas e anseios ainda maiores de consumo, e também o olhar de desejo daqueles(as) que não participam. Gera-se uma situação de instabilidade social. Outro fator primordial: a renda precisa estar associada à qualidade do atendimento à saúde e à educação ofertada.

Os mecanismos do uso da justiça precisam estar adequados à realidade social. Não há como diferenciar política, social ou economicamente o uso do sistema judiciário. A Justiça Restaurativa adquire um papel diferenciado na sociedade, como também no meio jurídico e educacional. O meio científico deve estar envolvido com suas propostas, pois várias outras áreas do conhecimento abordam-nas, e não podemos esquecer que este debate não é exclusividade do âmbito do Direito.

Desta feita, verificamos que

O sistema jurídico ocidental ou, mais especificamente, a justiça criminal, tem importantes qualidades. No entanto, vem crescendo o reconhecimento de suas limitações e carências. Não raro, vítimas, ofensores e membros da comunidade sentem que o sistema deixa de atender adequadamente às suas necessidades. Os profissionais da área da justiça-juízes, advogados, promotores, oficiais de 
condicional, funcionários do sistema prisional - amiúde expressam sua frustração com o sistema. Muitos sentem que o processo judicial aprofunda as chagas e os conflitos sociais ao invés de contribuir para seu saneamento e pacificação. (ZEHR, 20I2, p. 13)

A Justiça Restaurativa, para Zehr (20 I2, p. I 5), apresenta no seu cerne um conjunto de princípios, uma filosofia, uma série alternativa de perguntas paradigmáticas. Em última análise, a Justiça Restaurativa oferece estrutura alternativa para pensar as ofensas. Assim, a multiplicidade de ideias e ideais torna-se primordial e necessária, pois, mesmo que a Justiça Restaurativa abarque ampla gama de programas e práticas voltados para a restauração de conflitos, ainda se torna necessário que ocorra o compartilhamento de atitudes e ações entre todos(as).

O debate se configura como alavanca que irá modificar as estruturas relacionais entre as pessoas. Não há como estruturar uma demanda judicial apenas com o olhar daquele(a) que impetra a pena, a Justiça Restaurativa visa ser aplicada tanto naqueles(as) que são agressores(as) quanto naqueles(as) que são vítimas. Uma observação importante a ser feita é a de que, no meio social, o olhar de todos(as) está voltado para aqueles(as) que são as vítimas, mas, e os agressores(as)?

Devemos nos indagar se o ato de punir e cumprir uma pena são suficientes para eliminar ou restaurar o mal realizado. Ao fazermos essa indagação nos instigamos a avaliar o porquê de as prisões estarem cheias; dos altos índices de criminalidade na sociedade; da delinquência infanto-juvenil; e de tantos males que assolam a nossa sociedade e nossos(as) jovens. O que se tem feito para minimizar os males sociais e o distanciamento socioeconômico entre as pessoas?

Há uma "dívida" enorme a ser paga para uma grande parcela da população por décadas de descaso e invisibilidade social. O motivo por que precisam ser analisados os baixos índices de instrução. Sem educação de qualidade não se constrói uma cultura futura.

Assim, Zehr (20I2) aponta-nos que as estruturas relacionais se modificam quando ocorrem intervenções nos conflitos, mas há pontos importantes alertados pelo autor para não nos confundirmos, pois a Justiça Restaurativa não tem como objetivo principal o perdão ou a reconciliação, não é mediação, não tem por objetivo principal reduzir a reincidência ou ofensas em série, não é um programa ou projeto específico, não foi concebida para ser aplicada a ofensas comparativamente menores ou ofensores primários, não é algo novo nem se originou nos Estados Unidos, não é uma panaceia nem necessariamente um 
substituto para o processo penal, tampouco alternativa para o aprisionamento, também não se contrapõe necessariamente à justiça retributiva.

A Justiça Restaurativa atende à Justiça Retributiva, o delito torna-se algo que atenta contra a pessoa humana e os seus bens, o processo penal deve ser encaminhado. $\bigcirc$ que se dispõe com a Justiça Restaurativa é a reparação do ato ilícito o qual trouxe consigo muitos condicionantes que integram várias características de mal-estar, como raiva, indignação, desejo de justiça, medo e tantos outros. As ações legais determinadas pelo Estado e pela norma legal (positiva) são vistos, mas o que fazer para reparar o ato ilegal em si, não seria reparar o delito. E o que fazer para que vítima ou agredido(a), infrator(a) ou agressor(a) e comunidade possam estar em paz com o conflito/delito gerado.

Criam-se então condições para que a vítima possa acompanhar todas as ações ligadas ao delito que Ihe foi cometido, o que não ocorre em determinados casos ligados à Justiça Retributiva. Adverso a essa análise, Diniz (2003) enfatiza que no

[...] modelo da justiça restaurativa, à vítima é dado o direito de formular perguntas, não por intermédio de advogado e sob o crivo da análise da viabilidade jurídica da pergunta, mas sim diretamente e com a finalidade de obter respostas diretas do ofensor, obter uma compreensão, explicar o impacto que o evento danoso teve na sua vida e, assim, contribuir para o resultado final do processo, que pode alcançar um pedido de desculpa, restituição ou reparação de danos, serviços à comunidade ou outros. A justiça restaurativa, assim, cria um ambiente seguro no qual a vítima pode buscar aproximação do ofensor e pode expor as suas angústias, não somente para o juiz, mas para o ofensor. (p. 23)

que se discute é que as pessoas precisam verdadeiramente estar abertas para compreender, entender e relacionar os motivos e as motivações que levam ao delito. $\bigcirc$ ato em si, está feito, então o que fazer? Remoer a dor e sentimentos contrários ou buscar aplacar e compreender melhor essa dor? Ao interpor-se a restaurar o mal causado, o(a) agressor(a) subjetivamente repara o mal causado à vítima e à sociedade, e se estiver tomado de consciência, esta lhe trará conforto.

O movimento de Justiça Restaurativa começou como um esforço de repensar as necessidades que o crime gera e os papéis inerentes ao ato lesivo. Os defensores da Justiça Restaurativa examinaram as necessidades que não estavam sendo atendidas pelo processo legal corrente. Observaram também que é por demais restritiva a visão prevalente de quais os legítimos participantes ou detentores de interesse no processo judicial. (ZEHR, 20 I2, p. 24). 
Essa prática de solução de conflitos em seus princípios básicos configura desde 2002, como Resolução no Conselho Econômico e Social da Organização das Nações Unidas (ONU), que trata dos "Princípios básicos para utilização de programas de justiça restaurativa em matéria criminal". Como dito, essa Resolução interpõe que todos participem da solução dos problemas causados pelo delito/crime. Seguindo essa recomendação das Nações Unidas, alguns países já introduziram em sua legislação a prática restaurativa, como a Colômbia e a Nova Zelândia, e a tendência é que esse quadro aumente.

No Brasil, o processo de construção de debates e ações voltadas para a Justiça Restaurativa ainda são recentes. Nesse sentido, se observarmos a condição social da maioria de nossos(as) jovens que estão sob medidas socioeducativas, constata-se serem negros ou mulatos e pobres. Segundo Campos (2005), apesar

[...] de defendermos posturas consideradas corretas, enaltecendo a democracia, condenando as violações dos direitos humanos e as formas de exclusão social, muitas vezes deixamos aflorar arraigados preconceitos, atitudes discriminatórias que cultivamos quase inconscientemente e que nos acompanham desde os primórdios de nossas formações histórica e cultural. (p. |13).

Com a promulgação do Estatuto da Criança e do Adolescente (ECA), Lei n ${ }^{\circ}$ 8.069 de 1990, inicia-se uma nova fase relacional entre crianças e adolescentes que cometeram ato infracional e o Sistema Judiciário. Mas, ao se observar o ECA a partir de outra ótica, veremos que a sua consolidação ocorre

[...] no interior de uma cultura que durante um século cristalizou a crença de que a criança teria origem na família disciplinada e seria portadora de direitos, enquanto o menor seria aquele que a família não quis ou o Estado não pôde disciplinar; a este destinavam-se, preferencial e quase exclusivamente, medidas de cunho repressivo. (GONÇALVES, 2005, p. 36)

Atualmente, a Justiça Penal atua no sentido de observar o ato infracional pela ótica punitiva e retributiva. $O$ processo de ressocialização de âmbito legal é visto a partir dos condicionantes do Estatuto da Criança e do Adolescente, que assim determina:

Art. I 12. Verificada a prática de ato infracional, a autoridade competente poderá aplicar ao adolescente as seguintes medidas:

I - advertência;

II - obrigação de reparar o dano; 
III - prestação de serviços à comunidade;

IV - liberdade assistida;

$\checkmark$ - inserção em regime de semi-liberdade;

VI - internação em estabelecimento educacional;

VII - qualquer uma das previstas no art. IO I, Ia VI.

$\S 1{ }^{\circ}$ A medida aplicada ao adolescente levará em conta a sua capacidade de cumpri-la, as circunstâncias e a gravidade da infração.

$\S 2^{\circ}$ Em hipótese alguma e sob pretexto algum, será admitida a prestação de trabalho forçado.

$\S 3^{\circ}$ Os adolescentes portadores de doença ou deficiência mental receberão tratamento individual e especializado, em local adequado às suas condições. (BRASIL, 1990)

A partir do ECA, o olhar da criança e do(a) adolescente se modificou e a participação social na conjuntura da prevenção e da defesa se tornou mais eficaz. Nesse sentido, complementando as determinações do ECA, tem-se o Sistema Nacional Socioeducativo (SINASE), por meio da Lei $n^{\circ} 12.594$, de 2012, com vista a atender aos(as) adolescentes em conflito com a lei. $\bigcirc$ processo de ressocialização é visto como um meio voltado às práticas restaurativas, em seu artigo 35, em especial nos incisos II e III, nos quais esta Lei determina que:

Art. 35. A execução das medidas socioeducativas reger-se-á pelos seguintes princípios:

I - legalidade, não podendo o adolescente receber tratamento mais gravoso do que o conferido ao adulto;

II - excepcionalidade da intervenção judicial e da imposição de medidas, favorecendo-se meios de autocomposição de conflitos;

III - prioridade a práticas ou medidas que sejam restaurativas e, sempre que possível, atendam às necessidades das vítimas;

IV - proporcionalidade em relação à ofensa cometida;

$\checkmark$ - brevidade da medida em resposta ao ato cometido, em especial o respeito ao que dispõe o art. 122 da Lei no 8.069, de 13 de julho de 1990 (Estatuto da Criança e do Adolescente);

VI - individualização, considerando-se a idade, capacidades e circunstâncias pessoais do adolescente;

VII - mínima intervenção, restrita ao necessário para a realização dos objetivos da medida;

VIII - não discriminação do adolescente, notadamente em razão de etnia, gênero, nacionalidade, classe social, orientação religiosa, política ou sexual, ou associação ou pertencimento a qualquer minoria ou status; e

IX - fortalecimento dos vínculos familiares e comunitários no processo socioeducativo. (BRASIL, 20I2) 
Então, quando se comete um ato infracional e é menor de idade, ou em determinadas penas, a prática restaurativa se torna alternativa de pacificação social. Essa expressão é uma referência para a observância da Justiça Restaurativa. O que e vê no Brasil, são cadeias e penitenciárias lotadas, com todos os tipos de apenados, muitos esperando apenas um Habeas Corpus para serem soltos.

O processo de ressocialização, por meio de programas de aprendizado profissional e de inclusão no mercado de trabalho, leva os(as) adolescentes que cometeram ato infracional à sua reinserção na família e no ambiente de trabalho, mas se observa que essas situações praticamente inexistem. Nesse mesmo sentido, Zehr (20 I 2) aponta que

\footnotetext{
O sistema de justiça penal se preocupa com responsabilizar os ofensores, mas isto significa garantir que recebam punição que merecem. $\bigcirc$ processo dificilmente estimula o ofensor a compreender as conseqüências de sues atos ou desenvolver empatia em relação à vítima. Pelo contrário, o jogo adversarial exige que o ofensor defenda os próprios interesses, $\bigcirc$ ofensor é desestimulado a reconhecer sua responsabilidade e tem poucas oportunidades de agir de modo responsável concretamente. (p. 27)
}

O que mais ocorre é que o(a) ofensor(a), agressor(a) ou infrator(a), em muitos casos, não se sentem penalizados(as) pelos seus atos. Há certo distanciamento entre a realidade social e aquele(a) que comete um ato infracional ou um delito. Estses conceitos relacionais e essa realidade social precisam ser vistos e revistos para a promoção de uma cultura de paz. O que verdadeiramente ocorre, na maioria dos casos, é a ineficiência do sistema jurisdicional, pois, na maioria dos casos de violência, não há responsabilização, apenas penalização.

Ao se observar a Justiça Restaurativa, pode-se ver que nos seus princípios básicos a partir do momento em que se comete um ato infracional, o(a) infrator(a) deverá repará-lo (na medida do possível) de alguma forma. Ocorrendo processo reparatório, poderá haver a construção de uma cultura democrática e participativa, na qual haja o reconhecimento dos erros sociais e a retomada do processo de conscientização a partir da reparação dos danos. Essa premissa nos é apresentada por Zehr (20।2), pois

Não raro as vítimas se sentem ignoradas, negligenciadas ou até agredidas pelo processo penal. Isto acontece em parte devido à determinação jurídica do crime, que não inclui a vítima. $\bigcirc$ crime é definido como ato cometido contra o Estado, e por isso o Estado toma o lugar da vítima no processo. No entanto, em 
geral as vítimas têm uma série de necessidades a serem atendidas pelo processo judicial. (p. 25)

Esse processo reparatório também é visto na Lei sobre os Juizados Especiais Cíveis e Criminais (Lei no 9.099, de 1995), que prevê a composição civil para a reparação dos possíveis danos causados por um delito. Assim, a Justiça Restaurativa se for de conveniência do(a) juiz(a) poderá ser efetuada, desde que seguidos os trâmites legais cabíveis. Esta Lei, em seu art. 72, determina situações que preconizam a Justiça Restaurativa. O artigo afirma que,

Art. 72. Na audiência preliminar, presente o representante do Ministério Público, o autor do fato e a vítima e, se possível, o responsável civil, acompanhados por seus advogados, o Juiz esclarecerá sobre a possibilidade da composição dos danos e da aceitação da proposta de aplicação imediata de pena não privativa de liberdade. (BRASIL, 1995)

Essa composição de danos pode ser realizada a partir de outros processos e não apenas o da execução da pena. O processo mediativo também é possível em casos mais leves. Outro artigo que enfatiza essa prática na mesma Lei traz:

Art. 73. A conciliação será conduzida pelo Juiz ou por conciliador sob sua orientação.

Parágrafo único. Os conciliadores são auxiliares da Justiça, recrutados, na forma da lei local, preferentemente entre bacharéis em Direito, excluídos os que exerçam funções na administração da Justiça Criminal. (BRASIL, 1995)

O restauro das ações de um delito pode ser minimizado a partir das condutas do(a) infrator(a). A Lei no 9.099, de 1995, determina ser possível, tanto na fase preliminar quanto durante o procedimento contencioso, a derivação para o processo restaurativo; esta análise se faz presente no art. 89 que cita:

Nos crimes em que a pena mínima cominada for igual ou inferior a um ano, abrangidas ou não por esta Lei, o Ministério Público, ao oferecer a denúncia, poderá propor a suspensão do processo, por dois a quatro anos, desde que o acusado não esteja sendo processado ou não tenha sido condenado por outro crime, presentes os demais requisitos que autorizariam a suspensão condicional da pena.

$\S 1{ }^{\circ}$ Aceita a proposta pelo acusado e seu defensor, na presença do Juiz, este, recebendo a denúncia, poderá suspender o processo, submetendo o acusado a período de prova, sob as seguintes condições:

I - reparação do dano, salvo impossibilidade de fazê-lo; 
II - proibição de freqüentar determinados lugares;

III - proibição de ausentar-se da comarca onde reside, sem autorização do Juiz;

IV - comparecimento pessoal e obrigatório a juízo, mensalmente, para informar e justificar suas atividades.

$\S 2^{\circ} \bigcirc$ Juiz poderá especificar outras condições a que fica subordinada a suspensão, desde que adequadas ao fato e à situação pessoal do acusado.

$\S 3^{\circ}$ A suspensão será revogada se, no curso do prazo, o beneficiário vier a ser processado por outro crime ou não efetuar, sem motivo justificado, a reparação do dano.

$\S 4^{\circ} \mathrm{A}$ suspensão poderá ser revogada se o acusado vier a ser processado, no curso do prazo, por contravenção, ou descumprir qualquer outra condição imposta.

$\S 5^{\circ}$ Expirado o prazo sem revogação, o Juiz declarará extinta a punibilidade.

$\S 6^{\circ}$ Não correrá a prescrição durante o prazo de suspensão do processo.

$\S 7^{\circ} \mathrm{Se}$ o acusado não aceitar a proposta prevista neste artigo, o processo prosseguirá em seus ulteriores termos. (BRASIL, 1995)

Essas condutas estão associadas às formas de aceitação, por parte do(a) agressor(a), daquilo que Ihe fora imputado, segundo a sentença que the foi aplicada. Assim, a Justiça Restaurativa observa as implicações decorrentes dessa sentença, principalmente para as vítimas. Em relação às vítimas, Zehr (20|2) comenta que, devido à definição jurídica de crime e à natureza do processo penal, quatro tipos de necessidade parecem estar sendo especificamente negligenciadas.

Estes quatro tipos de necessidades, para Zehr (20 I 2), são: a) Informação; b) Falar a verdade; c) Empoderamento; d) Restituição patrimonial ou vindicação. Ao se interpretar essas necessidades, pode-se verificar não serem cotidianamente executáveis, todavia, não estão totalmente fora de questão.

Podem ser resumidas da seguinte forma: a Informação - a vítima precisa ter respostas às suas dúvidas e de como agir posteriormente; Falar a verdade - é preciso oportunizar que a vítima relate o acontecido e se busque a concretude dos fatos, mas o mais importante é ouvir a vítima, deixá-la narrar o acontecido; Empoderamento - é preciso que a vítima se sinta acolhida pelo sistema judicial e possa estar ciente de seus direitos e deveres como cidadão(ã), é preciso reconstruir o controle emocional e promover a autoestima; Restituição patrimonial ou vindicação - quando o agressor restitui à vítima um bem material, a perda se torna recompensada e o agressor oferece o seu pedido de desculpas. O importante nessa ação não é verificar o valor venal do bem, mas avaliar o valor simbólico do ato; o pedido de desculpas também é um ato que merece valor.

Nesse sentido, aos(as) agressores(as), a justiça precisa thes oferecer 
responsabilidades que podem estar, de acordo com Zehr (20 I 2), associadas aos seguintes comportamentos ou ações:

I. Cuide dos danos resultantes;

2. Estimule a empatia e a responsabilidade;

3. Transforme a vergonha.

4. Estímulo para a experiência de transformação pessoal;

5. Cura para os males que contribuíram para o comportamento lesivo;

6. Oportunidades de tratamento para dependências químicas e/ou outros problemas;

7. Aprimoramento de competências pessoais;

8. Estímulo e apoio para a reintegração à comunidade;

9. Para alguns, detenção, ao menos temporária. (p. 33)

A comunidade precisa ser ouvida e atendida no processo reparatório, mas o seu papel é importantíssimo, pois agressor e vítima precisam ser vistos pela comunidade como agentes de um processo restauratório, e o senso de agir em conjunto; todas as ações precisam estar em constante atuação para não ocorrerem dissipações de sentimentos e opiniões.

Ao imputar a pena, o Estado assume o lugar do(a) cidadão(ã), e a comunidade se isenta. Essa prática é comum em nossa sociedade. Essa condição de isenção se torna cotidiana, espera-se que o(a) outro(a) faça por mim. Sousa (20।3) questiona sobre um

[...] paradigma necessário de ser quebrado é o sentimento de que nenhuma outra resposta é possível de ser dada ao evento criminoso, a não ser a pena. [...] Dessa forma, a análise do crime do ponto de vista sancionatório, já não se admite vê-lo apenas com natureza retributiva-punitiva, mas observá-lo por um viés com finalidade utilitária alcançando-se, desta forma, a reeducação e recuperação do infrator. [...] Assim, a justiça restaurativa, na condição de solucionadora de conflitos, objetiva promover o fortalecimento das partes afetadas pela agressão, direta ou indiretamente, trazendo consigo a potencialização da coesão social na sociedade e comunidade (p. 100).

Mas, essa coesão e potencialização não ocorrem rapidamente, precisam ser digeridas e incorporadas ao cotidiano social. A sociedade espera que o

[...] Estado, diante do cometimento de uma infração penal, tem o poder-dever de aplicar uma sansão ao violador do ordenamento jurídico visando, consequentemente, a paz social, retribuindo-Ihe o malfeito com a aplicação de medidas por muitas vezes extrema. Dessa forma, ao longo do tempo, foi sendo aplicada a pena privativa de liberdade, tornando-se prática no modelo atual de justiça penal. Essa forma de resposta ao ilícito penal tem sido imposta como meio 
de prevenir reiterações dessas condutas, bem como ressocializar o infrator, o que, na prática, não se verifica o sucesso do seu intento. (SOUSA, 20 I3, p. I00)

Seguindo as diretrizes da Justiça Restaurativa, isso não poderá mais acontecer, todos(as) os(as) envolvidos(as) precisam fazer a sua parte. O Estado precisa criar condições para que não ocorram mediações de conflitos, e a comunidade possa realizar debates, fóruns, coleta de opiniões, sobre como agir em relação ao dano. O fortalecimento comunitário é importantíssimo, uma vez que essas comunidades precisam de que o sistema jurídico lhes ofereça:

\footnotetext{
- Atenção às suas preocupações enquanto vítimas.

- Oportunidades para construir um senso comunitário e de responsabilidade mútua.

- Estímulo para assumir suas obrigações em favor do bem-estar de seus membros, inclusive vítimas e ofensores, e fomento das condições que promovam convívio saudável. (ZEHR, 20 I2, p. 29)
}

Os valores primados pela Justiça Restaurativa baseiam-se na realidade e no trauma situacional da vítima ou do(a) agredido(a), há a necessidade de se observar quais foram os danos causados pelo delito. Todas as pessoas, agressor(a), agredido(a) e a comunidade precisam estar envolvidos(as) no processo restaurativo. As premissas da coletividade, da responsabilidade social e do compartilhamento de ideias e ideais devem ser verdadeiramente indicadores das relações entre as partes envolvidas.

Há necessidade também de que esse respeito mútuo seja centrado em conceitos voltados para a inclusão social, para a construção de um novo conceito cultural, e sejam utilizados nas abordagens jurídicas conceitos do Direito Alternativo, para que se possa criar uma rede de interligações entre todas as áreas do conhecimento.

A forma ou o contexto como esses valores podem ser realizados são precedidos de certos passos. Dentre esses passos, o maior envolvimento de pessoas (comunidade) é de fundamental importância. Deve-se sempre dar valor à fala de todos(as) respeitando-se a confiança e a confidencialidade de todas as decisões compartilhadas.

O que se deseja realmente com a Justiça Restaurativa é que ocorra a reparação do dano causado, seja por um pedido de desculpas, restituição de um bem ou pela prestação de serviços comunitários, $\bigcirc$ mais importante é que tanto para o(a) agressor(a) e o(a) agredido(a) todas essas atitudes de conciliação sejam acordadas, para que o mal-estar criado também seja aplacado ou 
reparado. As atitudes reparatórias e restaurativas precisam trazer para o(a) agressor(a) responsabilização dos seus atos, e para os(as) agredidos(as) participação em todo o processo, passando a ter voz e a opinar sobre o acontecido e suas consequências.

As responsabilidades e obrigações para reparar o dano são de competência de ambos os lados, tanto o agressor(a) quanto a vítima precisam estar voltados para o processo restaurativo, mas todo esse processo deve estar ligado primeiro às necessidades da vítima, posteriormente são vistas as obrigações do(a) agressor(a).

Segundo Zehr (20l2, p. 33), tanto a Justiça Criminal quanto a Justiça Restaurativa apresentam-se de duas formas diferentes, as suas visões são:

\begin{tabular}{|l|l|}
\hline \multicolumn{1}{|c|}{ Justiça Criminal } & \multicolumn{1}{c|}{ Justiça Restaurativa } \\
- O crime é uma violação da lei e do & $\begin{array}{l}\text { - O crime é uma violação de pessoas e de } \\
\text { relacionamentos. }\end{array}$ \\
Estado. & - As violações geram obrigações. \\
- As violaçães geram culpa. & A justiça envolve vítimas, ofensores e \\
- A justiça exige que o Estado determine & membros da comunidade num esforço \\
culpa e imponha uma punição & comum para corrigir a situação. \\
(sofrimento). & - Foco central: as necessidades da vítima e \\
· Foco central: os ofensores devem & a responsabilidade de o ofensor reparar o \\
receber o que merecem. & dano cometido. \\
\hline
\end{tabular}

Quadro 2. Visões da Justiça Criminal e Justiça Restaurativa. Fonte: Zehr (20|2).

Mas, para que, verdadeiramente, ocorram os procedimentos da Justiça Restaurativa, são apresentadas por Zehr (20I2, p.33) três perguntas diferentes que precisam ser analisadas e comparadas entre a Justiça Criminal ou Restritiva e a Justiça Restaurativa. Vejamos:

\begin{tabular}{|l|l|}
\hline \multicolumn{1}{|c|}{ Justiça Criminal } & \multicolumn{1}{c|}{ Justiça Restaurativa } \\
& \\
Que leis foram infringidas? & Quem sofreu danos? \\
Quem fez isso? & $\begin{array}{l}\text { Quais são suas necessidades? } \\
\text { - De quem é a obrigação de suprir essas } \\
\end{array}$ \\
\hline
\end{tabular}

Quadro 2.T rês perguntas da Justiça Criminal e Justiça Restaurativa.

Fonte: Zehr (20|2). 
Desse modo, Zehr (20/2) destaca três pilares centrais da Justiça Restaurativa, quais sejam:

[...] os danos e as conseqüentes necessidades (de vítimas em primeiro lugar, mas também da comunidade e dos ofensores); as obrigações (do ofensor , mas também da comunidade); e o engajamento daqueles que detêm legítimo interesse no caso e na sua solução (vítimas, ofensores e membros da comunidade). (p.36)

Nesse diapasão, a justiça deveria procurar resolver o delito, observando todas as partes e seus posicionamentos sobre o fato. Normalmente, apenas se observa quem cometeu o delito e qual punição deve-se ser aplicada. Mas quem sofreu o dano foi a vítima; então, pela ótica da Justiça Restaurativa, a abordagem do restauro deve começar por ela. As estruturas de relacionamento entre todos(as) fundamentam-se a partir da

[...] retificação dos males tem duas dimensões: I) tratar dos danos cometidos, e 2) tratar suas causas, inclusive os fatores negativos que contribuíram para o comportamento socialmente nocivo. (ZEHR, 20 I2, p. 44)

As vítimas são vistas como pessoas incapazes e inferiores por seus agressores(as). Essas pessoas devem procurar ultrapassar os obstáculos surgidos a partir dos contextos de violência. Essa capacidade de alterar seu comportamento, sua autoestima e a sua condição de vida, está associada ao comportamento resiliente.

A resiliência representa a conquista de uma pessoa sobre uma adversidade, sugere-se que os problemas cotidianos podem e devem ser ultrapassados. $\bigcirc$ que se objetiva é não esmorecer e buscar sempre uma possibilidade possível para solucionar qualquer situação em que se encontre. Essa força de vontade ou objetividade representa a vontade de solucionar esses problemas que ocorrem em nossas vidas.

Para Suanno (20I3), certas

[...] pessoas, nos momentos ruins e difíceis da vida, apenas enxergam a dificuldade em si e outras pessoas visualizam oportunidade para crescimento e aprendizagem. Estas últimas podem se superar e criar saídas, alternativas de enfrentamento da situação ou da dificuldade (p. 38).

Assim, ao buscar uma solução ou um novo caminho, essa pessoa altera o seu comportamento, demonstrando que consegue viver sob pressão 
emocional, principalmente quando se avalia alguma ação. Essa capacidade avaliativa está associada à percepção de cada pessoa sobre determinado comportamento; esse processo de consolidação de aprendizagens pela resiliência promove a

Criatividade e capacidade crítica aliadas, no dia a dia, são grandes diferenciais para o surgimento de ações inovadoras, visto que altera a autoimagem e o pensamento estratégico na busca de saídas para solução de problemas. (SUANNO, 2013, p. 31)

A busca por soluções de seus problemas poderá levar o indivíduo a pensar sobre si e sobre a sua relação com os(as) outros(as). Segundo Suanno (20।3, p.39), a oportunidade de refletir sobre adversidades e possíveis enfrentamentos possibilita a construção de saídas de alternativas, que contribuem para o autoconhecimento e o desenvolvimento da autoconfiança.

Ao se observar as propostas da Justiça Alternativa, vê-se, também, o desejo de buscar alternativas para solucionar um entrave ou delito social. A resiliência também é vista pela Justiça Restaurativa como uma necessidade premente a todos(as), pois, ao se instituir o restauro, as partes envolvidas devem estar voltadas para propostas de um recomeço. Precisa-se atentar que Justiça Restaurativa se preocupa, em última instância, com a restauração e reintegração de ambos: vítima e ofensor, além do bem-estar da comunidade como um todo. Portanto, ela procura tratar de todas as partes equilibradamente.

A Justiça Restaurativa busca, por meio de sua prática, atender a um novo posicionamento, representa a postura de alguém que realmente quer alterar o seu modo de viver e a sua condição de vida. $\bigcirc$ que se deseja, então, é o enfrentamento dos problemas apresentados cotidianamente na vida dos(as) jovens que se encontram em situação de conflito social, quer na família, na escola, no trabalho ou no meio social, senão esse choque de opiniões e desejos os(as) levará invariavelmente a condições de risco social, pois, ao enfrentar

[...] as adversidades as pessoas podem acumular experiências negativas e viver a lembrança das experiências com dor e sofrimento. Ou viver o que nunca deixará de ser uma experiência desagradável, sofrida, mas assumir uma postura resiliente, retirar da experiência da dor a possibilidade de novas aprendizagens de superação. [...] Podemos entender resiliência como a capacidade que o indivíduo tem de transformar-se na sua necessidade de obtenção de um ou mais objetivos de vida A resiliência é uma capacidade proativa, que fortalece a capacidade de prevenção, projeção e antecipação de cenários. (SUANNO, 2013, p. 40) 
Promover ações nas quais vítimas, agressores(as) e a comunidade envolvida possam se relacionar entre si não se constitui prática fácil de ser realizada, é preciso que ocorra um esforço conjunto entre todos. A resiliência representa um comportamento a ser seguido, necessário para que todos possam ultrapassar suas barreiras emocionais. Se não houver vontade de todos em modificar o conflito, não haverá saída para a sua solução.

A Justiça Restaurativa busca alterar essa forma de ver um conflito, em contraposição ao posicionamento da Justiça Retributiva, pois esta

[...] postula que a dor é o elemento capaz de acertar as contas, mas na prática ela vem se mostrando contraproducente, tanto para a vítima quanto para o ofensor. Por outro lado, a teoria da Justiça Restaurativa sustenta que o único elemento apto para realmente acertar as contas é a conjugação do reconhecimento dos danos sofridos pela vítima e suas necessidades ao esforço ativo para estimular o ofensor a assumir a responsabilidade, corrigir os males e tratar as causas daquele comportamento. Ao lidar de modo positivo com esta necessidade de vindicação ou acerto de contas a Justiça Restaurativa tem potencial de dar segurança a vítima e ofensor, ajudando-os a transformar suas vidas. (ZEHR, 20 I 2, p. 72)

Assim, ao buscar um caminho que possa representar uma saída, Zehr comenta que a Justiça Restaurativa se resume a uma série de perguntas que precisam ser feitas ao nos depararmos com o ato lesivo. Assim, as perguntas que sustentam a Justiça Restaurativa são:

\author{
-Quem sofreu o dano? \\ -Quais são suas necessidades? \\ - De quem é a obrigação de atendê-las? \\ - Quem são os legítimos interessados no caso? \\ - Qual o processo adequado para envolver os interessados num esforço para \\ consertar a situação? (ZEHR, 20 I2, p. 50)
}

A partir do momento em que procuramos responder a essas perguntas, estamos voltados para três modelos distintos que tendem a dominar a prática da Justiça Restaurativa: os encontros entre a vítima e o(a) ofensor(a), as conferências de grupos familiares e os círculos de Justiça Restaurativa. Dessarte, um dos caminhos alternativos que a Justiça Restaurativa nos apresenta e promove pode ser praticado por meio da utilização da Comunicação Não Violenta. 


\section{ACOMUNICAÇÃONÃO VIOLENTAE SUAS IMPLICAÇÕES}

A estrutura social predominante no Brasil é a paternalista, o espaço familiar centrado na figura do pai, provedor e centralizador das decisões familiares. Essa característica social foi ou ainda é uma realidade presente nas famílias brasileiras. A construção e a consolidação desses pensamentos estão centradas em nossas origens históricas.

A partir do início da década de 80 do século passado, com a abertura política e a inserção do Brasil em governos mais democráticos, novas perspectivas sociais e econômicas alteraram a concepção de família, a incorporação de novos modelos de vida trouxe novas formas de comportamento social. Mesmo assim, o diálogo ainda não representa no meio familiar brasileiro uma forma cotidiana de se encontrarem soluções para determinado problema, o que ainda vemos comumente são as estruturas associadas às questões de mando.

Em nossa cultura não há a predominância ou o hábito de se relativizar sobre os assuntos familiares ou sociais, nos centros urbanos encontramos estruturas recentes de diálogo, mas podemos dizer que ainda existem os conflitos de gerações. Esses conflitos intergeracionais promovem vários tipos de violência. $A$ Comunicação Não Violenta possibilita oportunidades de comunicação em várias situações sociais. A utilização da CNV em nossas interações coloca-nos num estado compassivo natural. Pode-se afirmar que a abordagem se aplica de maneira eficaz a todos os níveis de comunicação e a diversas situações:

- relações íntimas;

- famílias;

- escolas;

- organizações e instituições;

- terapias e aconselhamentos;

- negociações diplomáticas e comerciais;

- disputas e conflitos de toda natureza.

Pode-se exemplificar a falta de diálogo a situações nas quais a família centra as suas decisões apenas na figura do pai ou da mãe; aos(às) filhos(as) resta-lhes obedecer. É claro que existem decisões de competência exclusiva dos pais e das mães, mas há também outras situações que poderiam ser acordadas por todos(as).

Outra situação comprometedora ao diálogo está localizada nas escolas, estas centralizam as suas relações didático-pedagógicas na figura do(a) 
professor(a). Em muitas salas de aula inexiste o debate, a participação do(a) aluno(a) na construção do conhecimento, o que se vê em muitas situações de ensino é a "educação bancária". Podemos defender que a falta de diálogo ocorre em todas as profissões, a partir de diferentes situações de uso das relações de poder.

A Comunicação Não Violenta representa vir na contramão dessa estrutura social; a inexistência do diálogo é combatida. $O$ debate sobre determinado assunto representa a construção de como abordar os conflitos sociais, o ato de dialogar sobre um conflito favorece a ambas as partes, ofensor(a) e vítima, a paulatinamente desmontar os ressentimentos, as dores e a raiva criados.

A abordagem transformativa reconhece que o conflito é a dinâmica normal e contínua dos relacionamentos humanos. Além disso, o conflito traz consigo um potencial para mudanças construtivas. É claro que as mudanças nem sempre são construtivas. Sabemos bem que muitas vezes os conflitos resultam em ciclos de sofrimento e destruição que se estendem por longo tempo. Mas a chave para a transformação é manter um viés proativo e visualizar o conflito como um potencial catalisador de crescimento (LEDERACH, 20 I 2, p. 28).

Ao se observar esse crescimento, pode-se analisar que, quando os(as) agressores(as) são menores de idade, há duas formas jurídicas de se ater ao delito: pela ação punitiva, em que o réu(ré) é considerado(a) culpado(a) pelos seus atos, e o Estado usa de seu poder para puni-lo(a); ou a ação restaurativa, que visa ao diálogo entre as partes envolvidas no delito e estabelece medidas que vão desde a reparação do bem a um simples pedido de desculpas. Todas essas ações visam à busca da responsabilização dos atos cometidos e de novas formas de inserção no meio social.

Dentre essas novas formas de inserir o(a) adolescente no meio social, Rosenberg chama a atenção para o sentimento de compaixão, se não houver um olhar diferenciado para aquele(a) que agrediu, e para a vítima. As ações da Comunicação Não Violenta estarão comprometidas, pois estas representam a mediação de um conflito/delito, e esta é realizada por uma ou mais pessoas que estão cientes de seu papel e de suas responsabilidades, esta(s) pessoa(s) deve $(m)$ repassar para o(a) agressor(a) e ao(a) agredido(a) a sensação de segurança e confiança. $\bigcirc$ processo comunicativo ocorre em círculos que pleiteiam o olhar entre todos(as). Assim, os

[...] círculos se valem de uma estrutura para criar possibilidades de liberdade: liberdade para expressar a verdade pessoal, para deixar de lado as máscaras e defesas, para estar presente como ser humano inteiro, para revelar nossas 
aspirações mais profundas, para conseguir reconhecer erros e temores e para agir segundo nossos valores mais fundamentais. (PRANIS, 20 I2, p. 25)

Pranis (20 I 2) utiliza-se do termo "Círculo de Construção para a Paz", que pode ser associado às práticas relacionais utilizadas pela Comunicação Não Violenta. Ambos os termos preconizam a utilização da manutenção de conceitos pessoais e morais das pessoas e das suas relações com o meio social, todos os conceitos sociais devem ser respeitados, as opiniões de cada pessoa são importantes, mesmo que ocorram diferenças de valores.

Mas a Comunicação Não Violenta independe de ser apresentada previamente, pois a sua utilização baseia-se no princípio de que

[...] as pessoas com quem estamos nos comunicando não precisam conhecê-la, ou mesmo estar motivadas a se comunicar compassivamente conosco. Se nos ativermos aos princípios da CNV, motivados somente a dar e a receber com compaixão, e fizermos tudo que pudermos para que os outros saibam que esse é o nosso único interesse, eles se unirão a nós no processo, e acabaremos conseguindo nos relacionar com compaixão uns com os outros. Não estou dizendo que isso sempre aconteça rapidamente. Afirmo, entretanto, que a compaixão inevitavelmente floresce quando nos matemos fiéis aos nossos princípios e ao processo da CNV. (ROSENBERG, 2006, p. 24)

É preciso que se faça valer a respeitabilidade de opinião; relacionar o pedido de desculpas ou reparação à ofensa/delito, e que as partes envolvidas possam sentir minimamente o que o(a) outro(a) está retratando e emitindo, para que possa ser feito o restauro; e da análise de juízos de valores, é necessário que todos os fatos que geraram o delito sejam vistos e revistos por todos(as), sem que ocorram interferências de princípios; da relativização entre sentimentos e opiniões, e, ainda, que todos(as) possam se manifestar e ter a sua fala respeitada. Segundo Pranis (20 I 0, p. I 8), a filosofia subjacente aos Círculos reconhece que todos(as) precisam de ajuda, e ajudando os outros, estamos, ao mesmo tempo, ajudando a nós mesmos.

Ao se instituir o círculo restaurativo, há necessidade de se ter em mente que, tanto o(a) agressor(a) quanto a vítima está com medo, sentem-se ameaçados(as). Estão envergonhados(as), ressentidos(as), apresentam baixa autoestima, e a todo o momento têm o sentimento de que todas as pessoas ao seu redor estão acusando-os por serem agressores(as) ou por terem sido agredido(as). A sua funcionalidade requer que todos(as) os(as) participantes se sentem em

[...] cadeiras dispostas em roda, sem mesa ao centro. Às vezes se coloca no centro algum objeto que tenha significado especial para o grupo, como 
inspiração, algo que evoque nos participantes valores e bases comuns. $\bigcirc$ formato espacial do círculo simboliza liderança partilhada, igualdade, conexão e inclusão. Também promove foco, responsabilidade e participação de todos. (PRANIS, 2012, p. 25)

Ao realizar a Comunicação Não Violenta, abre-se a possibilidade da multiplicidade de opiniões e reflexões sobre o delito ocorrido. Em certos casos, outras pessoas envolvidas indiretamente ao fato podem participar, e até mesmo para a comunidade dos(as) envolvidos(as) a proposta reside no crescimento pessoal e comunitário de todos(as). Os exemplos criados a partir dos círculos restaurativos representam outras formas de se observar as relações humanas.

Seja qual for a sua denominação, esses Círculos estão

[...] sendo usados em variados contextos. Dentro dos bairros eles oferecem apoio para aqueles que sofreram em virtude de um crime - e ajudam a estabelecer a sentença daqueles que o cometeram. Nas escolas, criam um ambiente positivo na sala de aula e resolvem problemas de comportamento. No local de trabalho, ajudam a tratar de conflitos. No âmbito da assistência social, desenvolvem sistemas de apoio mais orgânicos, capazes de ajudar pessoas que estão lutando para reconstruir suas vidas. (PRANIS, 20 I 0, p. I6)

Todo processo da Comunicação Não Violenta está associado a conceitos ligados a todos os significados da palavra paz. Para que se possam alcançar os objetivos desejados ao iniciar-se a Comunicação Não Violenta, é preciso que o(a) facilitador(a) ou o(a) coordenador(a) saiba concretamente suas responsabilidades como mediador(a) do conflito no círculo. Para este membro, a paciência e dedicação aos processos restaurativos são de suma importância, o que se está em jogo é o ato lesivo e suas consequências, ou seja, o(a) agressor(a), ao praticar o delito, poderá em certas situações do cotidiano social não avaliar os sentimentos de quem foi agredido(a), e esses sentimentos precisam ser vistos por todos(as), principalmente pelo agressor(a).

Lederach (20 I 2) instiga-nos a analisar que uma

[...] estrutura transformativa salienta o desafio de como colocar fim a alguma coisa que não se deseja e como construir algo desejado. É importante lembrar que a abordagem transformativa liga as práticas resolutivas - que tradicionalmente buscam modos de pôr fim à iteração, ou repetição, de um conflito - a uma orientação transformativa, que atua construindo mudanças contínuas nos níveis relacional e estrutural. Por um lado, essa estrutura lida com os problemas prementes e com o conteúdo do conflito buscando soluções mutuamente aceitáveis para ambos - em geral processos que reduzem a violência e a escalada contínua de conflito. Por outro lado, vai além da 
negociação de soluções e lança os alicerces de algo novo. Isto requer a negociação de processos de mudança que surgem de uma compreensão ampliada dos padrões relacionais e do contexto histórico em disputa. (p.54)

Há indagações que precisam ser feitas para que possamos compreender melhor as situações de conflito. Torna-se necessário olharmos as nossas mínimas ações para que possamos compreender que, no cotidiano social, perdemos paulatinamente as estruturas relacionais e nos tornamos indivíduos insensíveis, sem sentimentos ou anseios comunitários. Agimos em conjunto porque todos(as) agem iguais; de modo geral, as ações humanas se tornam mecânicas e grupais, para o bem, o mal ou a indiferença.

Podemos situar que os locais onde mais ocorrem conflitos são o meio familiar e a escola. Nesses locais ocorrem os processos de iniciação relacional e também as situações de conflito. Na família, podem ocorrer casos de violência doméstica, alcoolismo, uso de drogas ilícitas, incompreensão, falta de amor familiar e tantas outras situações desagradáveis que interferem no comportamento da pessoa; essas situações familiares são deslocadas para a escola, local em que o(a) filho(a) irá reproduzir ou omitir todos os conflitos existentes na sua vida.

Nesse sentido, Pranis (20 l 0, p. 20 e 2 I) apresenta-nos várias situações para as quais devemos olhar, a fim de que os Círculos possam verdadeiramente apresentar resultados. Observemos essas situações a partir do quadro abaixo.

\section{VISÃO GERAL DOS CÍRCULOS}

Um Círculo de Construção de Paz é uma forma de reunir as pessoas, de modo que:

- Todos sejam respeitados;

- Todos tenham igual oportunidade de falar sem serem interrompidos;

- Os participantes se expliquem contando sua história;

- Todos são iguais. Ninguém é mais importante que o outro;

- Aspectos emocionais e espirituais da experiência individual são acolhidos.

Os Círculos de Construção de Paz são úteis quando duas ou mais pessoas:

- Precisam tomar decisões conjuntas;

- Discordam;

- Precisam tratar de uma experiência que resultou em danos para alguém; Querem trabalhar em conjunto como uma equipe;

- Desejam celebrar;

- Querem partilhar dificuldades;

- Desejam aprender uns com os outros. 
O Círculo de Construção de Paz é forte o suficiente para conter:

- Raiva;

- Frustração;

- Alegria;

- Dor;

- Verdade;

- Conflito;

- Visões de mundo diferentes;

- Sentimentos fortes;

- Silêncio;

- Paradoxos.

Quadro 2. Visão geral dos Círculos.

Fonte: Pranis.

Os Círculos se valem do respeito mútuo e da liberdade de expressão e opinião. São condições dos comportamentos humanos difíceis de serem alcançadas no mundo de hoje, mas necessárias para que se possa obter sucesso nas relações de conflito. Pranis (2010) atribui vários tipos de Círculos e, à medida que foram sendo aplicados para enfrentar diferentes problemas, emergiu uma terminologia para diferenciá-los segundo suas funções. Então, esses tipos podem ser apresentados nos Círculos de: Diálogo; Compreensão; Restabelecimento; Sentenciamento; Apoio; Construção de Senso Comunitário; Resolução de Conflitos; Reintegração; e Celebração.

Todos esses tipos de Círculos são influenciados pela comunhão de opiniões, não há como se pensar no processo de restauro se não houver a aceitação ou a tentativa de aceitação por ambas as partes no conflito.

Para que ocorra de forma satisfatória o Círculo Restaurativo, é necessário que este seja realizado em quatro estágios apresentados por Pranis (20 I0) da seguinte forma:

$1^{\circ}$ Estágio: Determinação de sua aplicabilidade. Esta é uma avaliação que visa estabelecer se o Círculo é um processo adequado para a situação, o que se faz através das seguintes perguntas:

- As partes principais estão dispostas a participar?

- A situação permite o tempo necessário para aplicação do Processo em Círculo?

- A segurança física e emocional dos envolvidos pode ser garantida?

$2^{\circ}$ Estágio: Preparação

- Identificação das partes que devem participar: Quem sofreu os impactos da 
situação? Quem tem os recursos, habilidades, conhecimentos necessários? Quem tem experiência de vida similar que possa representar uma contribuição?

- Familiarizar as partes principais com o processo;

- Começar a estudar o contexto do problema.

$3^{\circ}$ Estágio: Encontro de todas as partes

- Identificar os valores partilhados e desenvolver os princípios orientadores;

- Iniciar a contação de histórias a fim de criar relacionamentos e conexões;

- Partilhar preocupações e esperanças;

- Expressar sentimentos;

- Examinar as causas subjacentes do conflito ou danos;

- Gerar idéias para sanar os danos e resolver conflitos;

- Determinar as áreas de consenso para agir;

- Desenvolver acordos e explicitar responsabilidades.

4 Estágio: Acompanhamento

- Avaliar o progresso dos acordos. Todas as partes estão cumprindo suas obrigações?

- Examinar as causas de qualquer descumprimento de obrigações, esclarecer as responsabilidades e identificar os próximos passos, caso o descumprimento persista;

- Adaptar os acordos conforme a necessidade. Com base em novas informações e acontecimentos;

- Celebrar o sucesso. (p.61 e 62)

O Círculo Restaurativo por meio da Comunicação Não Violenta pode ser visto a partir da ótica de Rosenberg, como um "estado de libertação emocional", quando realizada com sucesso produz sensações que influenciam a forma de os(as) envolvidos(as) verem as suas atitudes. Segundo Rosenberg (2006), a sua construção deve passar por três estágios, cada um representa como agressor(a) e vítima se sentem ao participarem do círculo e, também, em como nos relacionamos com as outras pessoas no nosso cotidiano. Esses estágios são assim apresentados:

Estágio I: Nesse estágio, que eu costumo denominar escravidão emocional, acreditamos que somos responsáveis pelos sentimentos dos outros. Achamos que devemos nos esforçar constantemente para manter todos felizes. [...] Estágio 2: Nessa fase, tomamos consciência do alto custo de assumir a responsabilidade pelos sentimentos dos outros e por tentear satisfazê-los em detrimento de nós mesmos. [...] Estágio 3: Na terceira etapa, a libertação emocional, respondemos às necessidades dos outros por compaixão, nunca por medo, culpa ou vergonha. Desse modo, nossas ações estão nos realizando, assim como aqueles que são o objeto de nossos esforços. Aceitamos total responsabilidade por nossas intenções e ações, mas não pelos sentimentos dos 
outros. Nesse estágio, temos consciência de que nunca poderemos satisfazer nossas próprias necessidades à custa dos outros. (p. 91, 92 e 94)

Em resumo, para Rosenberg, no primeiro estágio nós nos vemos como responsáveis pelos sentimentos das outras pessoas; isso se torna uma "escravidão emocional". Estamos presos não aos nossos sentimentos, mas aos sentimentos que acreditamos que o(a) outro(a) possui. No segundo estágio, o autor o denomina de "sentimento ranzinza", nesse momento, sentimos raiva, não queremos mais ser responsáveis pelos sentimentos dos outros. No terceiro estágio ocorre a "libertação emocional", esta nos leva a assumir a responsabilidade por nossas ações e intenções, então tomamos consciência das nossas limitações.

A construção da Comunicação Não Violenta é gradual, deve ser vista como um processo em que etapas precisam ser seguidas; o ir e vir torna-se necessário para que sejam observados todos os caminhos percorridos. A Comunicação Não Violenta altera a forma de viver das pessoas, deve centrar-se no compartilhamento, na harmonia, no companheirismo, no respeito e em muitos outros termos. Infelizmente, nos Círculos ou nas relações cotidianas, o que encontramos é a raiva, a hipocrisia, o cinismo e a violência.

Assim, a comunicação entre as pessoas precisa estabelecer relações plenas de convívio, e este estabelecer representa permitir que um(a) possa opinar, gritar, chorar, falar mal do(a) outro(a), manifestar-se livremente, expor seus sentimentos e angústias, ter a possibilidade de desabafar e ser rebatido(a). A possibilidade de se expressar e expor seus sentimentos são de fundamental importância para o sucesso do Círculo. Há necessidade de realmente se praticar o uso da empatia.

Rosenberg (2006) indica-nos que essa comunicação precisa estar fundada na observação e na avaliação, pois a Comunicação Não Violenta

\footnotetext{
[...] acarreta necessariamente que se separe observação de avaliação. Quando combinamos observações com avaliações, os outros tendem a receber isso cmo crítica e resistir ao que dizemos. A CNV é uma linguagem dinâmica que desestimula generalizações estáticas. Em vezdisso, as observações devem ser feitas de modo específico, para um tempo e um contexto determinado. (p. 57)
}

Atualmente, a divergência de opinião, cultura ou credo apresenta a possibilidade da construção de sentimentos opostos, levando-nos a ter opiniões diferentes uns(umas) dos(as) outros(as) e, em última instância, a promover contextos de violência. Muitos destes contextos de violência estão relacionados aos sentimentos ou ações ligadas à vergonha, ao ato de rotular e 
julgar o(a) outro(a), a raiva, a culpabilidade, a invisibilidade social, ao egoísmo e há tantos outros. A maioria de nós cresceu usando uma linguagem que, em vez de nos encorajar a perceber o que estamos sentindo e do que precisamos, estimula-nos a rotular, comparar, exigir e proferir julgamentos (ROSENBERG, 2006, p. 47).

Em muitos casos relacionais, ficamos presos à lógica destrutiva, e não à lógica construtiva. Para muitas pessoas, essa maneira de ser se torna destrutiva. Os diferentes contextos da Comunicação Não Violenta visualizam a cooperatividade entre todos(as) que estão presentes no Círculo, pois as relações de convívio devem levar a todos(as) um processo de unidade e harmonia; em contrapartida, um tipo de comunicação alienante da vida é o uso de julgamentos moralizadores que subentendem uma natureza errada ou maligna nas pessoas que não agem em consonância com nossos valores (ROSENBERG, 2006, p. 37).

No Brasil, existem várias Instituições que apoiam a Comunicação Não Violenta, como a MEDIARE, Justiça para o Século 2 I e a CNVBrasil, dentre outras. A CNVBrasil apoia seus aprendizados com o auxílio de várias pessoas, dentre estas o

[...] de Dominic Barter, membro da equipe do Dr. Rosenberg e coordenador do Projeto de Língua Portuguesa do Centro Internacional de Comunicação NãoViolenta. CNVBrasil é formada em rede como uma comunidade de aprendizado. Ela valoriza a capacidade que todos têm de contribuir para a educação de outros e destaca a interdependência do saber e fazer no processo de co-aprendizado. Assim, reflete os valores que dissemina. A rede é autosustentada e aberta a todos num espírito de livre troca (ROSENBERG, 2006, p. 92).

Mas esse processo de co-aprendizado deve, invariavelmente, influenciar para que a sociedade possa se contrapor a todas as atrocidades por ela enfrentadas. Devemos avaliar a todo o momento em nossas relações cotidianas, por exemplo, como reagimos a alguma ação contraditória sob nosso ponto de vista. Para Campos (2005) tudo aquilo

[...] que para nós muitas vezes é tido como uma verdade incontestável nem sempre corresponde às nossas próprias expressões práticas, ao nosso comportamento cotidiano. Todos concordamos que a paz é a mais salutar forma de conveniência entre os povos, que o trabalho bem remunerado é fator preponderante na geração do bem-estar social e que a educação representa o mais eficiente instrumento de evolução da humanidade. Contudo, a guerra, a exploração do homem pelo homem e o analfabetismo, dentre outras necedades, continuam presentes entre nós, contrariando nossas pretensas 
aspirações a uma vida plena de paz, justiça social e progresso. (p. I I3)

Assim, a possibilidade de se averiguarem os erros e acertos de uma ação ou delito, faz-nos pensar e compreender o mundo que nos cerca. Implica alterar a insensibilidade da sociedade. Tudo isso só se consolida com a construção de novos conceitos culturais e educacionais.

Não há mais possibilidade de ficarmos presos à situação de delegar nossas expectativas aos sistemas jurídico e político. $\bigcirc$ comportamento massificador de esperar que o(a) outro(a) faça por nós o que em muitos casos nós mesmos poderíamos fazer, torna-se uma situação de conforto para uns(umas) e insustentável para outras pessoas. A Comunicação Não Violenta aprofunda as relações entre as pessoas. Ao permitir e estimular que todos(as) participem do debate proposto, constitui-se em atitudes relacionais entre todos(as), pois, quando

[...] expressamos nossas necessidades indiretamente, através do uso de avaliações, interpretações e imagens, é provável que os outros emitem nisso uma crítica, E, quando as pessoas ouvem qualquer coisa que soe como crítica, elas tendem a investir sua energia na autodefesa ou no contra-ataque. [...] Infelizmente, a maioria de nós nunca foi ensinada a pensar em termos de necessidades. Estamos acostumados a pensar no que há de errado com as outras pessoas sempre que nossas necessidades não são satisfeitas. (ROSENBERG, 2006, p. 95)

Podemos enfatizar esse pensamento a partir das necessidades individuais e coletivas das pessoas numa sociedade capitalista, pois o individual prevalece ao invés do coletivo, as pessoas estão amarradas ao processo de consumo, esquecem-se das relações de sociabilidade comunitária em que propostas alternativas de resolução de conflitos ou até mesmo de comunicação entre as pessoas se tornam incomuns.

\section{A COMUNICAÇÃO NÃO VIOLENTAE A ESCOLA}

Todo o processo de Comunicação Não Violenta se baseia no aprendizado, e a escola possui uma representatividade enorme na formação do indivíduo. $\bigcirc$ ambiente escolar é um local onde existem muitos conflitos, e estes podem gerar delinqüência, em decorrência da rebeldia, como uma resposta aos tratamentos recebidos.

A escola trabalha com parâmetros rígidos, em que a disciplina, a execução de tarefas e o comportamento único precisam ser utilizados para um melhor controle, mas, em muitas escolas, professores(as) e gestores(as) não estão 
preparados(as) para absorver todas as implicações que o meio social traz para seu interior.

Muitos(as) destes(as) profissionais não recebem nem receberam qualquer tipo de capacitação para lidar com as questões de violência; até mesmo outros(as) profissionais de outras áreas que atuam dentro e em seu entorno, assim, o(a) aluno(a) que apresenta mau comportamento ou rendimento escolar deve, necessariamente, se adaptar ao sistema de ensino que lhe é apresentado. Se isso não ocorrer, provavelmente este(a) aluno(a) será excluído(a) desse sistema, podendo ocorrer, provavelmente, a repetência e a evasão escolar. Esse insucesso acarreta transtornos ainda maiores, pois a angústia e a raiva pelo insucesso podem ser refletidas para a sociedade.

Não se está a criticar o agir pedagógico das escolas, mas sim analisando possíveis situações de conflito que tanto professores(as) quanto alunos(as) passam. Incita-se um diálogo que não quer dizer que, para não obter essa realidade, as escolas não devam utilizar-se da aprovação e da reprovação como medidas educativas. $\bigcirc$ que se debate são os condicionantes necessários para evitar os riscos sociais.

Ao se analisar o sistema educativo, vê-se que os(as) professores(as) não têm condições de auxiliar aluno(a) por aluno(a); esse(a) profissional normalmente promove a massificação de condutas. Nesse processo, os(as) alunos(as) que estão com determinados problemas passam despercebidos(as). As escolas deveriam ter outros(as) profissionais atuando em seu meio, como psicólogos, assistentes sociais, médicos, policiais e outros mais, para que o processo de educação pudesse ser completo.

A educação não se resume ao ambiente escolar, ela se constrói na família, no cotidiano social. Devemos avaliar verdadeiramente as condições de vida de crianças e adolescentes que cometeram ato infracional, situarmo-nos na esfera do(a) outro(as). Quais são os motivadores que implicam um comportamento voltado para o delito, à contradição de normas sociais pré-estabelecidas?

Precisamos observar que, cada vez mais, estamos envoltos em ações de nosso cotidiano que nos levam a agir segundo o(a) outro(a), e não a partir do que se pensa e deseja. $\bigcirc$ comportamento coletivo se torna massificador e interfere na maneira de pensar. Não estamos criticando os comportamentos sociais, não produzimos cultura ou não modificamos a cultura existente.

\section{CONSIDERAÇÕES}

A partir das observações sobre a Justiça Restaurativa e a Comunicação Não 
Violenta, podemos destacar uma conclusão dentre tantas outras apresentadas. Ao ocorrer o envolvimento das práticas relacionais, vê-se a necessidade de agir em conjunto, pois, ao compartilharmos decisões e angústias, os(as) envolvidos(as) sentem-se como comunidade e como seres humanos. A proposta mais enfatizada por todos(as) aqueles(as) que defendem a Justiça Restaurativa e a Comunicação Não Violenta é a prática do senso de coletividade; este precisa ser visto e revisto constantemente, mais ainda, ser respeitado.

A Justiça Restaurativa representa um novo agir social, apresenta a possibilidade da promoção de resolução de conflitos em outra esfera relacional. A possibilidade de se construir um referencial que se contraponha ao existente (Justiça Retributiva) e consolide a democracia participativa. Poderá vir a se tornar um determinante importantíssimo para todos(as) os(as) brasileiros(as).

A sua construção requer inúmeras modificações no pensar e agir já construído e consolidado pela sociedade, principalmente pelos(as) gestores(as) do Poder Público. É preciso enfrentar novos desafios que representem a possibilidade da construção de novas relações solidárias entre as pessoas. A solidariedade, a democracia, a cidadania, o respeito aos direitos humanos são palavras que precisam ter sentido em nossas vidas. Não há mais como conviver com a falta de perspectiva política e social.

Todas as ações relacionadas à Comunicação Não Violenta se voltam para as premissas da consolidação de novas estruturas ou instâncias relacionais para que não estejamos presos à barbárie, e sim para que possamos ter como sentido de vida o convívio humano.

A sociedade brasileira passou por um longo período de obscuridade, mas a possibilidade de poder construir o verdadeiro sentido da democracia nos direciona ao combate à demagogia; a sua representação determina combater o estado de inércia e a falta de representatividade. $\bigcirc$ maior malefício à desconstrução da democracia está associado ao ato de calar quando o(a) incomodado(a) ou ofendido(a) não se manifestar, ficar resignado a partir do silêncio e do medo tornam-se as piores respostas à democracia.

Ao permitir que todos(as) possam influenciar nos processos decisórios; a dividir entre todos(as) as responsabilidades; ao consolidar o compromisso para a solução de um conflito; ao construir o comprometimento à reconciliação e à reparação do dano, então todos(as) devem participar do processo restauratório.

Em muitas situações cotidianas, a maior parte da população se utiliza de práticas sociais ligadas à não participação nas ações e decisões voltadas para o 


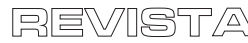

bem público, a dizer não para tudo e para todos(as), a preocupar-se com as fraquezas das outras pessoas, e não com as suas, a não zelar pelos interesses da Nação e do Patrimônio Público; estes e outros comportamentos negativos se contrapõem às virtudes necessárias para com o(a) outro(a) e para com a sociedade.

O compromisso da responsabilidade conjunta possa verdadeiramente ser utilizado continuamente. Quantas vezes procuramos o(a) outro(a) que foi ofendido(a) por nós, para lhe pedir desculpas? Em muitas situações, guardamos dentro de nós a ofensa e nos fechamos no ressentimento e na mágoa, o pior é que, em muitos casos, não manifestamos essa ofensa e ainda expomos quem nos ofendeu. Ao expormos as razões pelas quais estamos ofendidos (vítima) e ao ouvir as razões por ser ofendido (agressor(as)) criamos uma comunicação que visualiza a busca da não violência entre todos(as).

\section{REFERÊNCIAS}

ALMEIDA,Tânia. Justiça restaurativa e mediação de conflitos. Disponível em:<http://www.mediare.com.br/08artigos_06justica_restaurativa.html >. Acesso em I 5/8/2014.

BRASIL. Estatuto da Criança e do Adolescente(ECA), Lei n 8.069/90.

BRASIL. Sistema Nacional Socioeducativo (SINASE), Lei n I 2.594// 2

BRASIL. Juizados Especiais Cíveis e Criminais - Lei n 9.099/95

CAMPOS, Fernando Soares. Adolescentes infratores acautelados: uma caricatura dos sistemas penitenciários. In: ZAMORA, Maria Helena. Para além das grades: elementos para a transformação do sistema socioeducativo. Rio de Janeiro: Ed. PUC/Rio, 2005.

DINIZ, Geilza Fátima Cavalcanti. Aplicabilidade da justiça restaurativa nos casos de violação a direitos da personalidade no âmbito dos Juizados Especiais Cíveis. In: Revista dos Juizados Especiais: Doutrina e Jurisprudência. Tribunal de Justiça do Distrito Federal e dos Territórios. Vol. I, n I, Brasília: $\bigcirc$ Tribunal, 2003.

GONÇALVES, Hebe Sigmorini. Medidas socioeducativas: avanços e retrocessos no trato do adolescente autor de ato infracional. In: ZAMORA, 
Maria Helena. Para além das grades: elementos para a transformação do sistema socioeducativo. Rio de Janeiro: Ed. PUC/Rio, 2005.

GRECO, Alessandra Orcesi Pedro. A autocolocação da vítima em risco. São Paulo: Ed. Revista dos Tribunais, 2004.

LEDERACH, John Paul. Transformação de Conflitos. São Paulo: Ed. Palas Athena, 2012.

PRANIS, Kay. Processos circulares. São Paulo: Ed. Palas Athena, 2010.

ROSENBERG, Marshall B. Comunicação Não-Violenta: Técnicas para aprimorar relacionamentos pessoais e profissionais. São Paulo: Ed. Ágora, 2006.

ROSENBERG,Marshall. Sobre a Comunicação Não-Violenta. Disponível em: $<$ http://www.palasathena.org.br/arquivos/conteudos/Sobre_a_CNV_Marsha \|_ Rosenberg.pdf >. Acesso em I5/8/20|4.

ROSENBERG, Marshall. CNVBrasil, 2006. Disponível em: <www.cnvbrasil.org >. Acesso em 15/8/20I4.

ROSENBERG, Marshall. Comunicação Não-Violenta. Disponível em: $<$ http://pt.slideshare. net/katafrakta/comunicao-no-violenta-marshall-brosenberg > . Acesso em I 5/8/20 I 4.

SOUSA, Serugue Almeida. Justiça Restaurativa: uma alternativa eficaz. In: Entre Aspas: Revista da UNICORP. Tribunal de Justiça do Estado da Bahia, v.3, n³, p. 99- I | 6. Salvador: Universidade Corporativa do TJBA, 2013.

SUANNO, João Henrique. Adversidade, Resiliência e Criatividade: uma articulação oportuna? In: SUANNO, Marilza Vanessa Rosa; DITTRICH, Maria Glória; MAURA, Maria Antônia Pujol (Org.). Resiliência, Criatividade e Inovação: potencialidades transdisciplinares na educação. Goiânia: UEG/Ed. América, 2013 
ZEHR, Howard. Justiça Restaurativa. São Paulo: Ed. Palas Athena, 2012.

. Trocando as lentes: um novo foco sobre o crime e a justiça. São Paulo: Ed. Palas Athena, 2008

Recebido em: 28/06/2015 Aprovado em: II/08/2015 